\title{
Novel Porous Forsterite Ceramics Biocompatibility and Bioactivity Evaluation
}

\author{
MARIA GOREA ${ }^{1}$, MARIETA-ADRIANA NAGHIU ${ }^{1}$, ALEXANDRA AVRAM ${ }^{1 *}$, IOAN PETEAN ${ }^{1}$, \\ AURORA MOCANU ${ }^{1}$, MARIA TOMOAIA-COTISEL ${ }^{1,2 *}$ \\ ${ }^{1}$ Babes-Bolyai University, Faculty of Chemistry and Chemical Engineering, Department of Chemical Engineering, \\ Physical Chemistry Center, 11 Arany Janos Str., 400028, Cluj-Napoca, Romania \\ ${ }^{2}$ Academy of Romanian Scientists, 54 Splaiul Independentei, 050094, Bucharest, Romania
}

\begin{abstract}
This study is aimed to evaluate the biocompatibility and bioactivity of some new porous forsterite ceramics (FCs) produced from high-purity nano forsterite powder, synthesized by an original sol-gel method, which was subjected to pressing into pellets, by using a poly vinyl alcohol solution as a binding component. Then, the raw pellets were sintered at $1200{ }^{\circ} \mathrm{C}, 1300{ }^{\circ} \mathrm{C}, 1400{ }^{\circ} \mathrm{C}$ and $1450{ }^{\circ} \mathrm{C}$. The obtained four forsterite ceramics, FC-1200, FC-1300, FC-1400 and FC-1450, were fully characterized by density, porosity and shrinkage measurements. The forsterite ceramics exhibited excellent biocompatibility determined by an in vitro cell viability assay, such as MTT test. Furthermore, the in vitro bioactivity test was performed by immersing the forsterite ceramics into simulated body fluid $(S B F)$ and examining the hydroxyapatite (HAP) formation on forsterite ceramics, as evidenced by XRD, FTIR, SEM with EDX. Moreover, the relationship between porous structure and bioactivity of forsterite ceramics in SBF as well as the performance of FC in a cell culture was evaluated. The findings strongly recommend these forsterite ceramics for biomedical applications, as potential bone substitutes.
\end{abstract}

Keywords: forsterite ceramics, cell viability, bioactivity in $S B F$, hydroxyapatite formation

Recently, a new class of forsterite ceramics (FCs), obtained from forsterite nanoparticles, has become a subject of intense exploration as promising biomaterials for medical applications [1-7]. Due to antibacterial activity, the forsterite ceramic might be a proper candidate for load bearing applications [1]. Surely, more scientific research is needed to assess the usage of bioactive forsterite ceramics for load bearing bone and denture prosthesis. In this respect, it is already recognised that the in vitro and in vivo performance of nanostructured forsterite ceramics depends on various factors, like the stability of forsterite structure, which is influenced by both preparation conditions of nano forsterite powder and fabrication method of forsterite ceramics [8-12].

Various procedures, such as sol-gel method, sol-gel combustion method, solid-state reaction, and microwave approach, just to name a few, were used to synthesize pure nano forsterite powder [13-21]. The phase purity of synthesized forsterite was reached at high temperatures by slow diffusion rates within magnesium silicate systems.

Further, forsterite ceramics can even provide promising alternatives for the replacement of a bone part, [22] due to its expected high bioactivity, which is inherited from forsterite nanoparticles [14]. Furthermore, it may improve cells attachment and proliferation and, thus, it might generally reduce the necessary time for osseointegration of implanted materials, as has recently been demonstrated [23]. As such, the development of new forsterite ceramics is a continuing progress.

Moreover, forsterite $\left(\mathrm{Mg}_{2} \mathrm{SiO}_{4}\right)$ possesses good bioactivity due to its high content of $\mathrm{Si}$ and $\mathrm{Mg}$, which can be released from forsterite, in vivo, and, are necessary in bone development. For instance, silicon is believed to be required in the initial stages of the calcifying process, increasing the mineralization of young bone, while magnesium has been proven to contribute to skeletal mass gain [19, 24, 25]. It is recognized that when released into a biological environment, for instance in simulated body fluid, SBF, Si and $\mathrm{Mg}$, are replaced by $\mathrm{Ca}$ and $\mathrm{P}$ ions [26] leading to the formation of a hydroxyapatite (HAP) layer on the surface of forsterite particles [14].

In our previous work, nano forsterite powder was synthesized using sol-gel and solid-state reaction methods, and characterized both physico-chemically using XRD, FTIR, SEM, AFM, SEM-EDX and biologically in SBF and in cell culture, as bone substitutes and resorbable implants [14-16]. Additionally, biocomposites of nano forsterite highly dispersed in a polymeric matrix were prepared and structurally and biologically characterized, their mechanical properties being evaluated for orthopedic and dental applications [17].

*email:aavram@chem.ubbcluj.ro; mcotisel@gmail.com 
Furthermore, these findings indicate that both nano forsterite powder and forsterite ceramics can lead, in vivo, to a proper effect on bone calcification [24] and bone repair [27-28]. and they can be a potential biomaterial for tissue engineering. However, systematic studies on nano forsterite production coupled with its sinterability leading to porous forsterite ceramics of high bioactivity remain rare. From an engineering viewpoint, the densification of forsterite nanoparticles into forsterite ceramics to reach a proper porosity is an important subject for various medical applications, but the relationship between density, porosity and sintering behaviour of nano forsterite in forsterite ceramics has not been examined in detail for medical applications. So, the present study investigated this relationship in the resulted samples sintered between 1200 and $1450{ }^{\circ} \mathrm{C}$, and correlated the findings with both the bioactivity of forsterite ceramics in SBF and their biocompatibility in cell culture.

In this investigation, the main objective was to develop forsterite ceramics of various porosities, and to assess their quality testing through sintering behavior of nano forsterite powder. A detailed study was also performed for in vitro evaluation of both the biocompatibility in cell culture and bioactivity in SBF of forsterite ceramics.

\section{Experimental part \\ Preparation of forsterite ceramics}

To synthesize the forsterite ceramics, nanostructured forsterite powder was used. The nano forsterite $\left(\mathrm{Mg}_{2} \mathrm{SiO}_{4}\right)$ powder was synthesized according to our previous study [14] by using the sol-gel method. Briefly, hexahydrated magnesium nitrate $\mathrm{Mg}\left(\mathrm{NO}_{3}\right)_{2} .6 \mathrm{H}_{2} \mathrm{O}$, Merck, was dissolved in an appropriate quantity of pure water and mixed with tetraethyl orthosilicate, TEOS, $\mathrm{Si}\left(\mathrm{OC}_{2} \mathrm{H}_{5}\right)_{4}$ from Merck. The Mg:Si molar ratio was 2:1, which corresponds to the theoretical value for pure forsterite. The mixture was homogenized for $2 \mathrm{~h}$ by using magnetic stirring device. Then, sucrose and nitric acid were added as $\mathrm{pH}$ regulators. Then, the mixture was heated up to $80{ }^{\circ} \mathrm{C}$ and stirred for another $2 \mathrm{~h}$. The final obtained mixture was preserved for $24 \mathrm{~h}$ at room temperature to allow the gel formation. Subsequently, the dried gel was heated in two steps at 800 and $900{ }^{\circ} \mathrm{C}$, with $2 \mathrm{~h}$ plateau at each high temperature. The obtained nanostructured forsterite was of high purity crystalline phase fired at $900^{\circ} \mathrm{C}$, containing crystallite sizes smaller than $60 \mathrm{~nm}$ and only minor trace of periclase $(\mathrm{MgO})$.

Further, to prepare the forsterite ceramic, the nano forsterite powder was mixed with a $2 \%$ poly vinyl alcohol (PVA, purchased from Sigma-Aldrich) solution, leading to a $6 \%$ humidity of the granulated mixture. The mixture was uniaxially pressed into compact disc-shaped pellets, with a diameter of $6.2 \mathrm{~mm}$ and a height of $2 \mathrm{~mm}$ at a specific pressure of $500 \mathrm{kgf} / \mathrm{cm}^{2}(49.03 \mathrm{MPa})$.

Subsequently, the dried samples (at $120^{\circ} \mathrm{C}$ ) were thermally treated and sintered in air at temperatures of 1200 , 1300,1400 and $1450{ }^{\circ} \mathrm{C}$ in a Nabertherm laboratory kiln at a heating rate of $3{ }^{\circ} \mathrm{C} / \mathrm{min}$, for a $2 \mathrm{~h}$ plateau at each selected sintering temperature. Then, the furnace was cooled at a rate of $10^{\circ} \mathrm{C} / \mathrm{min}$ to room temperature, the pellets being deposited in a desiccator until further use. For the simulated body fluid investigation and for cell culture tests the same types of pellets were used.

\section{Characterization of forsterite ceramics}

Density, porosity and linear shrinkage

The compactness characteristics of sintered samples were evaluated according to Archimedes' principle [29-33] by weighing each sample in both air and water in a specific equipment (Precisa hydrostatic balance) using the immersion test. This test was carried out on each forsterite ceramic to determine the relative and apparent (bulk) density as well as total and apparent porosity. For this purpose, three input data are needed, namely the mass of dried sample in air, $\mathrm{m}_{0}$, the mass of sample immersed in water, $\mathrm{m}_{1}$, and the mass of sample saturated with water (i.e. sample with free bubbles on its surface), but determined in air, $\mathrm{m}_{2}$ [31-32]. To increase the accuracy of the immersion mass and of saturated mass, it is recommended that each sample should be kept in boiling water for at least $2 \mathrm{~h}$, before the immersion test. The reason is related to the fact that boiling water can better penetrate both the pores and the structural holes within the sample [31].

The apparent (bulk) density $\left(\mathrm{Da}, \mathrm{g} / \mathrm{cm}^{3}\right)$ and apparent porosity $(\mathrm{Pa}, \%)$ of sintered samples were calculated by the following equations (1) and (2):

where $d$ is water density.

$$
\begin{aligned}
& \mathrm{Da}=\mathrm{m}_{0} \mathrm{~d} /\left(\mathrm{m}_{2}-\mathrm{m}_{1}\right) \\
& \mathrm{Pa}=\left[\left(\mathrm{m}_{2}-\mathrm{m}_{0)} /\left(\mathrm{m}_{2}-\mathrm{m}_{1}\right)\right] \times 100(\%)\right.
\end{aligned}
$$

The relative density $(\mathrm{D}, \%)$ was determined by comparing the theoretical density of forsterite $\left(\mathrm{D}_{\mathrm{th}}=3.221 \mathrm{~g} / \mathrm{cm}^{3}\right)$ and its bulk (apparent) density, Da, [30].

The relative density $(\mathrm{D}, \%)$ and total porosity $(\mathrm{P}, \%)$ of sintered samples were calculated by the following equations (3) and (4), respectively:

$$
\begin{aligned}
& \mathrm{D}=\left(\mathrm{Da} / \mathrm{D}_{\mathrm{th}}\right) \times 100=(\mathrm{Da} / 3.221) \times 100 \\
& \mathrm{P}=\left[\mathrm{D}_{\mathrm{th}}-\mathrm{m}_{0} \mathrm{~d} /\left(\mathrm{m}_{2}-\mathrm{m}_{1}\right)\right] \times 100 / \mathrm{D}_{\mathrm{th}}
\end{aligned}
$$


The linear shrinkage, LS, of the sintered sample was determined by measuring the change in length (or in diameter) of each sample, using a digital calliper, before sintering $\left(\mathrm{L}_{0}\right)$ and after sintering $(\mathrm{L})$ at a particular temperature, and calculated $(\%)$ by the following equation:

$$
\mathrm{LS}=\left[\left(\mathrm{L}_{0}-\mathrm{L}\right) / \mathrm{L}_{0}\right] \times 100(\%)
$$

The results (relative density, total porosity and linear shrinkage, all in \%) are obtained as mean values with corresponding SD values. Each experiment was repeated at least three times for each forsterite ceramic.

\section{$\underline{X-R a y ~ D i f f r a c t i o n ~(X R D) ~}$}

The crystalline compounds of forsterite ceramics before and after immersion in SBF were determined using a Bruker D8 Advance diffractometer, with Co $\mathrm{K} \alpha_{1}=1.79026 \AA$, operated at $35 \mathrm{kV}$ and $40 \mathrm{~mA}$. The pattern was collected for a 29 range of 5 to $65^{\circ}$, with a step size of $0.02 \% \mathrm{sec}$.

A unique forsterite crystalline phase was detected at all sintering temperatures, $1200,1300,1400$, and $1450^{\circ} \mathrm{C}$. However, a minor content of $\mathrm{MgO}$ was also detected at $1200{ }^{\circ} \mathrm{C}$ showing that this sintering temperature is good enough to eliminate a secondary phase. This finding signifies that the formation of forsterite structure was almost complete even for FC-1200.

\section{Morphology and particle size}

Scanning electron microscopy (SEM) images were obtained on a Hitachi TM-1000 low-vacuum benchtop microscope with $15 \mathrm{kV}$ accelerating voltage on uncoated samples (working distance 14-16 mm) while the energy dispersive X-ray spectroscopy (noted EDS or EDX) was carried out using a Si-drift detector with an ultra-thin Be window.

Atomic force microscopy (AFM) imaging was performed on a Jeol JSPM 4210 scanning probe microscope, operated in tapping mode, using specific cantilevers produced by Micromasch Co., having a spring constant of $40 \mathrm{~N} / \mathrm{m}$ and a resonant frequency of $325 \mathrm{kHz}$. Different macroscopic areas were investigated at different scanning areas ranging from $10 \mu \mathrm{m} \times 10 \mu \mathrm{m}$ to $1 \mu \mathrm{m} \times 1 \mu \mathrm{m}$ and surface roughness was evaluated.

\section{FTIR spectra}

The formation of crystalline hydroxyapatite was evidenced by the presence of $\mathrm{PO}_{4}{ }^{3-}$ and $\mathrm{OH}^{-}$ions identified on the forsterite ceramics, by using a FTIR Jasko 6100 instrument in the spectral range of $4000-400 \mathrm{~cm}^{-1}$ with a resolution of $4 \mathrm{~cm}^{-1}$.

\section{In vitro bioactivity}

To demonstrate the formation of hydroxyapatite on the surface of forsterite ceramics, the pellets were immersed in $\mathrm{SBF}$ for 1,2 and 3 months at a solid / liquid ratio $=1.5 \mathrm{mg} / 1 \mathrm{~mL}$, without changing the SBF. The temperature of samples immersed in SBF was kept constant, at $37^{\circ} \mathrm{C}$, throughout the entire experiment. After the selected time, the FC was taken out from SBF and washed with distilled water to remove the SBF, and then dried at $100^{\circ} \mathrm{C}$. The SBF was prepared according to the procedure described by Kokubo and Takadama [26].

\section{Forsterite ceramic (FC) scaffolds}

To improve bioactivity, the FC ceramics (scaffolds) were degreased by ultra-sonication, and cleaned in ethanol solution before sterilization. The FC pellets were sterilized using a Getinge K5+ machine. The sterilization steps included initial vacuum, sterilization with ethylene oxide, final vacuum, and desorption of ethylene oxide. The sterilization parameters were temperature $37^{\circ} \mathrm{C}$, at low vacuum, for $180 \mathrm{~min}$ sterilization time. After, the ceramics were placed on the well bottoms of a 24-well plate.

Then, about 50000 cells per well were seeded by counting them with a hemocytometer. The changing of the medium was performed every 2 days using the same standard culture medium. Cell cultivation on forsterite ceramic, FC-1200, took place at 3days (3d), $7 \mathrm{~d}$ up to $14 \mathrm{~d}$, incubated at $37^{\circ} \mathrm{C}$, under a humidified atmosphere of $5 \% \mathrm{CO}_{2}$.

\section{Fibroblasts culture}

Human fibroblast from lung, HFL cells (ATCC number: CCL-153, normal lung fibroblasts derived from a Caucasian fetus) were used for testing the scaffolds` biocompatibility. Cells were detached from culture plates with trypsin 0.025 EDTA for 5 min. Trypsin was inactivated with medium containing $10 \%$ fetal bovine serum and cell suspension was centrifuged $5 \mathrm{~min}$ at $1000 \mathrm{rpm}$. The cells were between the fourth and sixth passages. Cells viability was checked with $0.4 \%$ trypan blue, and cells were counted with a hemocytometer. These cells were cultured at $37^{\circ} \mathrm{C}$ and $5 \% \mathrm{CO}_{2}$ in a humidified incubator. 
The in vitro evaluation of biocompatibility of forsterite ceramics (FC) as scaffolds was achieved by introducing the FC pellets into the HFL cells, cultured in Dulbecco's Modified Eagle's Medium (Invitrogen), DMEM supplemented with Nutrient Mixture F-12 HAM medium with $10 \%$ fetal calf serum (FCS) and proper amount of penicillin and streptomycin.

\section{Cell Viability}

Forsterite ceramic, FC-1200, was subjected to cells viability test to determine its biocompatibility in vitro [5, 3439]. The MTT assay is preferred over the other methods of measuring cells viability as it is a sensitive and reliable indicator of the cellular metabolic activity [35, 37, 38].

The colorimetric MTT assay is a sensitive and reliable indicator of cell viability in terms of enzymatic conversion of the soluble tetrazolium MTT yellow dye to water insoluble purple formazan crystals by dehydrogenases occurring primarily in the mitochondria of living cells.The MTT compound is 3-(4,5 dimethylthiazol-2-yl)-2,5 diphenyltetrazolium bromide, which is positively charged and easily penetrates viable cells. The enzymatic reduction of MTT dye to MTT-formazan is catalysed mainly by mitochondrial oxidoreductase. The insoluble formazan purple crystals are then solubilized from treated viable cells by dimethyl sulfoxide, DMSO. Then, the resulted dispersions were analyzed spectrophotometrically at about $570 \mathrm{~nm}$ giving an estimate of the extent of biocompatibility.

For MTT assay, $5 \times 10^{4}$ cells/well were suspended in $1 \mathrm{~mL}$ complete medium and seeded on the surface of sterilized scaffolds placed in 24-well plates; each type of scaffold was in triplicate. Scaffolds without cells were used as controls. It was determined that no corrections were necessary due to the adsorption of MTT compound or of formazan compound on forsterite ceramic, FC-1200 scaffolds.

The plates were incubated at $37^{\circ} \mathrm{C}, 5 \% \mathrm{CO}_{2}, 95 \%$ humidity for different points of time. Determination of cells viability/proliferation by MTT assay was performed after 3, 7 and 14 days. Scaffolds were transferred into other 24well plates and exposed for $1 \mathrm{~h}$ at $37^{\circ} \mathrm{C}$ in dark to $1 \mathrm{~mL} /$ well of $5 \mathrm{mg} \mathrm{MTT} / \mathrm{mL}$ solution (Thyazolyl Blue tetrazolium Bromide, MTT, from Sigma Aldrich) solubilized in Hanks solution without phenol red.

MTT is a tetrazolium salt which is converted under the action of mitochondrial reductases present in viable cells into a formazan compound (purple/dark blue) that is insoluble in aqueous solutions and soluble in DMSO. MTT test is used mainly as a viability test, but indirectly is also an indicator of cell growth and proliferation.

To perform the MTT test, fibroblasts were cultured on the FC-1200 scaffolds for 3d, 7d and 14d and their viability and proliferation rates were determined by OD measurements according to the manufacturer's instructions (SigmaAldrich). At a particular chosen time, the medium was picked up from the wells; and $1 \mathrm{ml}$ of MTT solution was added to each well, then warmed to $37^{\circ} \mathrm{C}$ for $1 \mathrm{~h}$, following MTT cell uptake. Then, after the removal of the supernatant, 1.5 $\mathrm{mL}$ of DMSO (Merck) was added to each well to dissolve the entire amount of purple formazan crystals. For measuring the optical density, the aliquots of $100 \mu \mathrm{L}$ of supernatant were transferred into a 96-well plate and the optical density was measured with a SUNRISE - Tecan microplate reader at a wavelength of $570 \mathrm{~nm}$, which is characteristic for formazan product with an absorbance maximum near $570 \mathrm{~nm}$.

The results are given as OD units. The OD measured at $570 \mathrm{~nm}$ monitors the formazan product and is directly proportional to the number of viable cells in vitro. Three specimens for FC-1200 were tested for each incubation time, 3 days (3d), $7 \mathrm{~d}$ and $14 \mathrm{~d}$ (the end of the culture period) and each test was performed at least for three times. Results were reported as OD units, and mean value was calculated $(n=9)$ and given jointly with its standard deviation (SD). The obtained optical density values were subjected to GraphPad Prism 5 statistical analysis using repeated measures ANOVA and Bonferroni's Multiple Comparison Test, $\mathrm{p}$ value was set at 0.05.

The results revealed an increase of OD values within the time frame between 3 and 7 days, with statistical significance $(* * * p<0.001)$. The growth of the cells slowed after 7 days, with similar values at 14 days. The results from MTT assay were validated by fluorescein diacetate (FDA) staining, which showed the increase in the number of cells at the same time intervals.

\section{$\underline{\text { Statistical analysis }}$}

GraphPad Prism 5 was used for statistical analysis. All data are defined as the mean value \pm standard deviation (SD) of at least three independent experiments. Significant differences were identified using the one-way ANOVA and Tukey`s multiple comparison test. For MTT assay, significant differences were identified by one-way ANOVA and Bonferroni's multiple comparison test. Differences among samples were considered statistically significant if $\mathrm{p}<0.001$, or otherwise stated.

\section{Results and discussions}

\section{Forsterite ceramics characterization}

The forsterite ceramics shrinkage

During thermal treatment, the forsterite ceramics (FCs) underwent some dimension changes depending on their structural characteristics, like porosity, density, and the sintering temperature, 1200, 1300, 1400 and $1450{ }^{\circ} \mathrm{C}$ used in 
the fabrication process for the obtained FCs, called FC-1200, FC-1300, FC-1400, and FC-1450. The linear shrinkage $(\%)$ of FC samples sintered at different temperatures is shown in Figure 1.

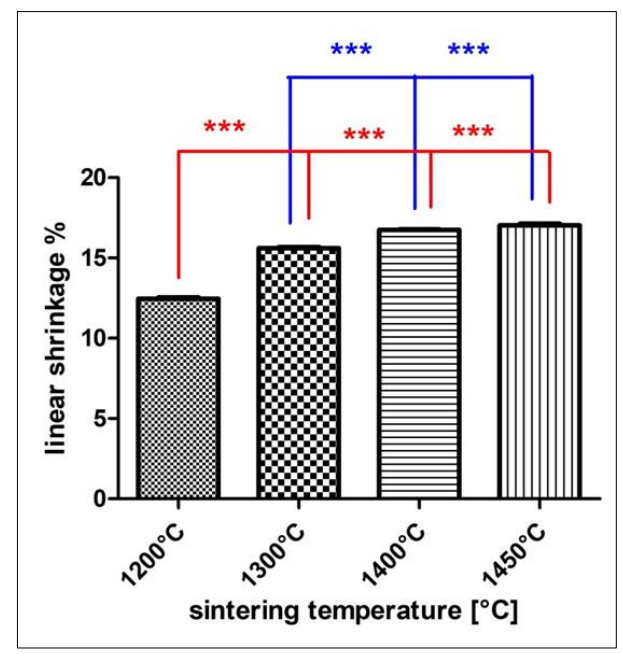

Fig. 1. Linear shrinkage (LS) of forsterite ceramics (FCs) versus sintering temperature. Error bars stand for standard deviation (SD); the tips of error bars just touch the average values, indicating high data quality with an excellent reproducibility. Data are given as mean \pm SD. Statistically significant differences for $\mathrm{p}<0.001$ are $(* * *)$ marked

As indicated in Fig. 1, the statistical analysis showed a significant difference between linear shrinkage (LS) for FC1200 vs FC-1300, and FC-1400, and FC-1450 (red stars), as well as for FC-1300 vs FC-1400, and FC-1450 (blue stars), for $\mathrm{p}<0.001$; while LS for FC-1400 vs LS for FC-1450 were not statistically different, $\mathrm{p}>0.001$. The following order FC-1200< FC-1300<FC-1400, was found for $\mathrm{p}<0.001$. So, the highest LS value (\%) of $16.73 \pm 0.13$ was found for FC-1400. These data, shown in Fig. 1, revealed that FC-1400 is apparently the best regarding the compactness of particles in the fosterite ceramics potentially of interest for bone repair defects.

\section{Compactness characteristics of forsterite ceramics}

The compactness characteristics of forsterite ceramics, relative density, total porosity and linear shrinkage are mainly dependent on the thermal treatment. In the following, it is important to emphasize that the linear shrinkage for forsterite ceramic, $\mathrm{FC}-1450$, sintered at $1450^{\circ} \mathrm{C}$ is not statistically significantly different from the corresponding value for FC-1400. Therefore, the linear shrinkage up to only $1400^{\circ} \mathrm{C}$, together with the relative density and total porosity are given in Figure 2.

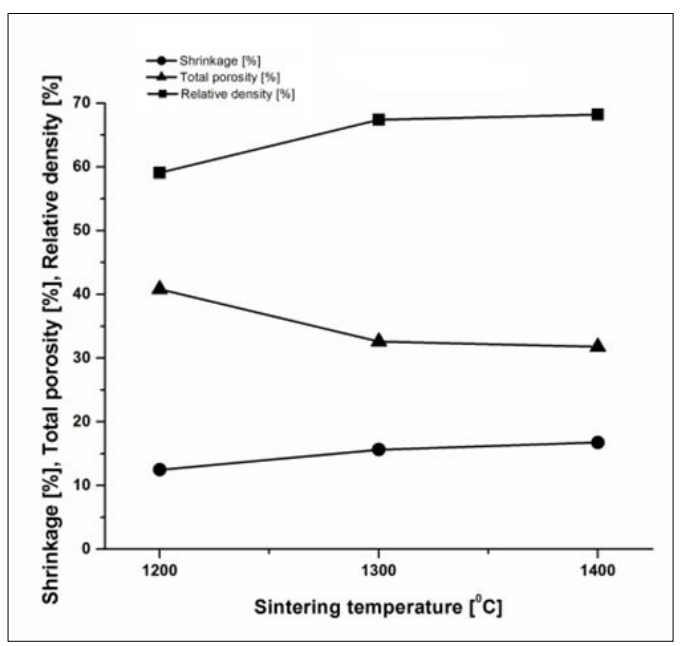

Fig. 2. Linear shrinkage, total porosity and relative density for forsterite ceramics versus sintering temperature

As shown in Figure 2, the linear shrinkage $(\%)$ values show a nearly linear increase, with significant differences among all FCs in the temperature interval from 1200 to $1400{ }^{\circ} \mathrm{C}$, from $12.46 \pm 0.16 \%$ to $16.73 \pm 0.13 \%$. There is a nonlinear dependence for relative density vs sintering temperatures. The relative density increased from $59.1 \pm 0.8 \%$ to $68.2 \pm 0.6 \%$, with significant difference between FC-1200 vs FC-1300 and FC- 1400 , for $\mathrm{p}<0.05$, but without significant difference between FC-1300 vs FC-1400, p >0.05. The total porosity values displayed also non-linear dependence vs sintering temperatures. The total porosity decreased from $40.83 \pm 0.11 \%$ to $31.77 \pm 0.08 \%$ with significant differences among all FCs.

It is important to point out that the FC-1200 was selected for in vitro biocompatibility and SBF bioactivity evaluation of its scaffolds. The logic behind this is that the FC-1200 has proper characteristics given in Fig. 2, which are comparable with previous data obtained on similar forsterite ceramics, fired at higher temperatures between 1350 
and $1550{ }^{\mathrm{c}} \mathrm{C}$, and used in cell culture [4]. Therefore, the $\mathrm{FC}-1200$ is a good material to conduct further biocompatibility and bioactivity tests on.

\section{Bioactivity evaluation of forsterite ceramics as scaffolds}

X-ray diffraction (XRD) investigation

The XRD pattern for forsterite ceramic with the highest porosity, prepared at $1200^{\circ} \mathrm{C}$, before and after immersion in the SBF for 1, 2 and 3 months, are shown in Figure 3.

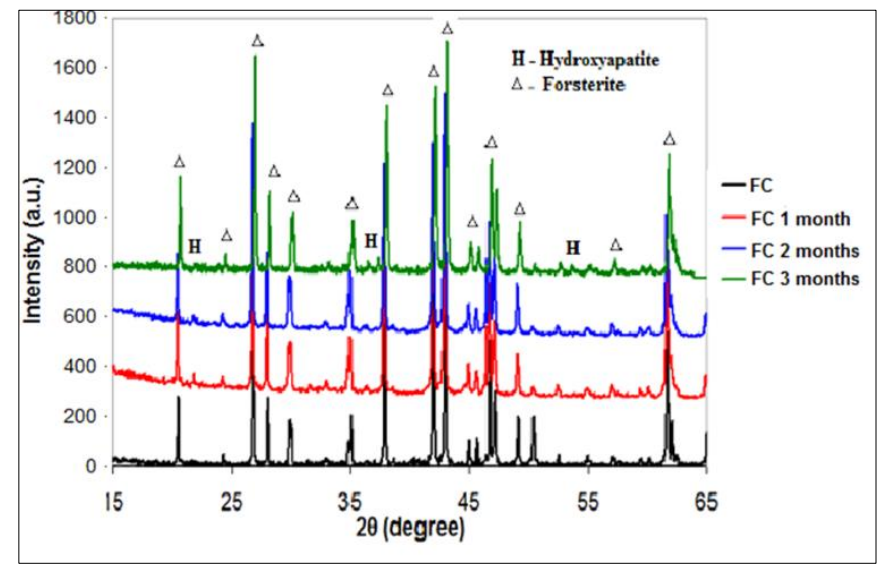

Fig.3. X-ray diffraction pattern for forsterite ceramic, FC-1200, sintered at $1200{ }^{\circ} \mathrm{C}$ before and after immersion in SBF, for various time periods

As evidenced by previously studied nano forsterite powders [14], hydroxyapatite is crystallized on the particle surface after immersion in SBF. The hydroxyapatite formation on porous ceramic samples is revealed by XRD after the first month of immersion. After, 2 or 3 months, the hydroxyapatite peaks are well-evidenced.

Fourier-transform infrared (FTIR) spectroscopy

Figure 4 shows FTIR spectra of forsterite ceramic, FC-1200, sintered at $1200{ }^{\circ} \mathrm{C}$ after immersion in the SBF. The specific vibration bands of $\mathrm{Si}-\mathrm{O}$ in $\left[\mathrm{SiO}_{4}\right], \mathrm{Mg}-\mathrm{O}$ in $\left[\mathrm{MgO}_{6}\right]$ for forsterite are well evidenced alongside the $\mathrm{P}-\mathrm{O}$ bonds from $\left[\mathrm{PO}_{4}\right]$ groups of hydroxyapatite.

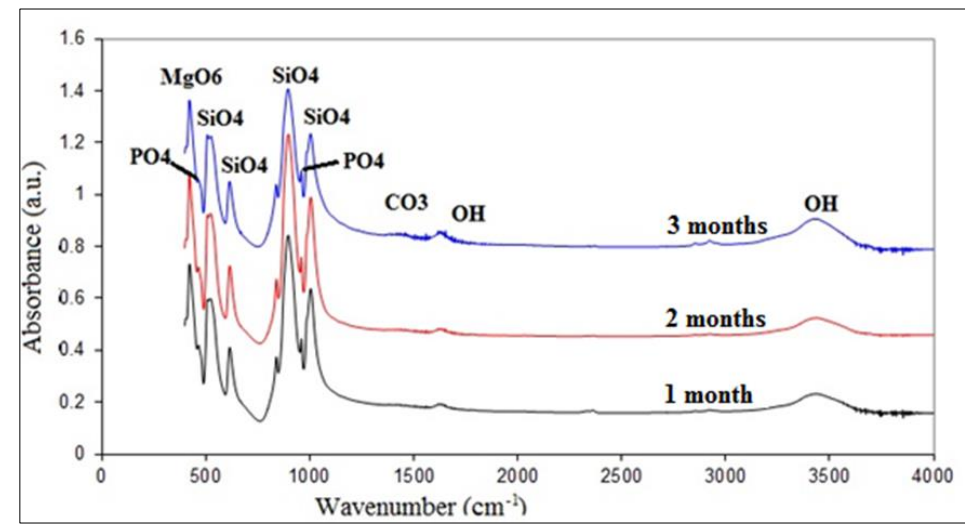

Fig. 4. FTIR spectra of forsterite ceramic sintered at $1200{ }^{\circ} \mathrm{C}$, maintained for 1,2 respectively 3 months in SBF

The intense absorption band of hydroxyapatite is evidenced at about $1044 \mathrm{~cm}^{-1}$. The $\mathrm{P}-\mathrm{O}$ asymmetric distortion band is cleaved in two peaks, at around 566 and $603 \mathrm{~cm}^{-1}$. The large band at $3600-3300 \mathrm{~cm}^{-1}$ is attributed to the $\mathrm{O}-\mathrm{H}$ vibrations in adsorbed water molecules. The $\mathrm{CO}_{3}{ }^{2-}$ asymmetric stretching vibration band, present at $1400 \mathrm{~cm}^{-1}$, is attributed to the presence of carbonate ions in SBF and their interaction with newly formed HAP crystals. The absorption bands specific to hydroxyapatite $\left(\mathrm{PO}_{4}, \mathrm{CO}_{3}\right.$ and $\mathrm{OH}$ groups) are well identified after 3 months of immersion in SBF.

Scanning electron microscopy (SEM) with energy dispersive spectroscopy (EDS)

The SEM image for surface morphology and the EDS spectrum obtained on forsterite ceramic, FC-1200 fired at $1200^{\circ} \mathrm{C}$, immersed in SBF for 3 months are shown in Figure 5. 


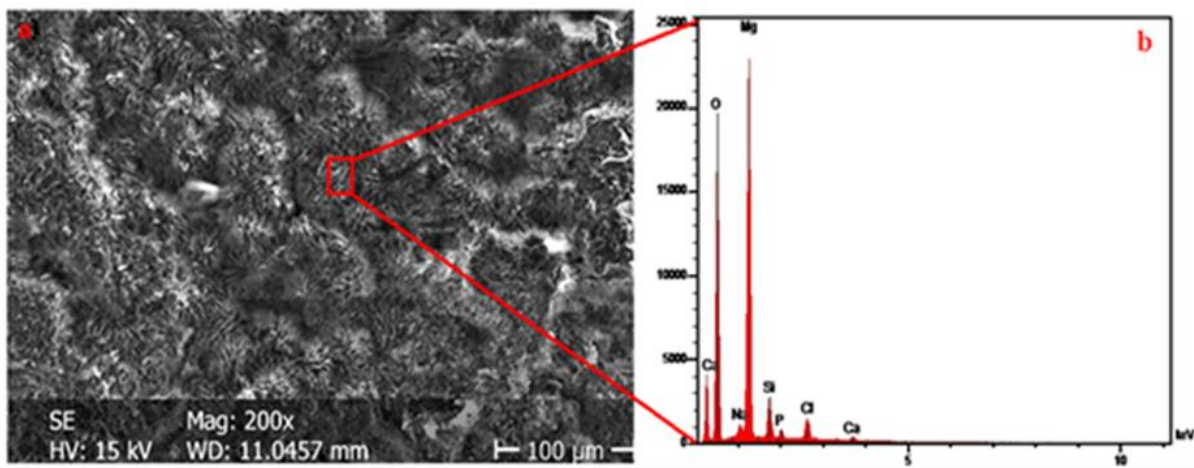

Fig. 5. SEM image (a) and EDS spectrum (b) for forsterite ceramic fired at $1200{ }^{\circ} \mathrm{C}$, after 3 months of immersion in SBF

Similarly, SEM image and EDS spectrum are given in Fig. 6, for FC-1400 fired at $1400{ }^{\circ} \mathrm{C}$, and immersed in SBF for 3 months.
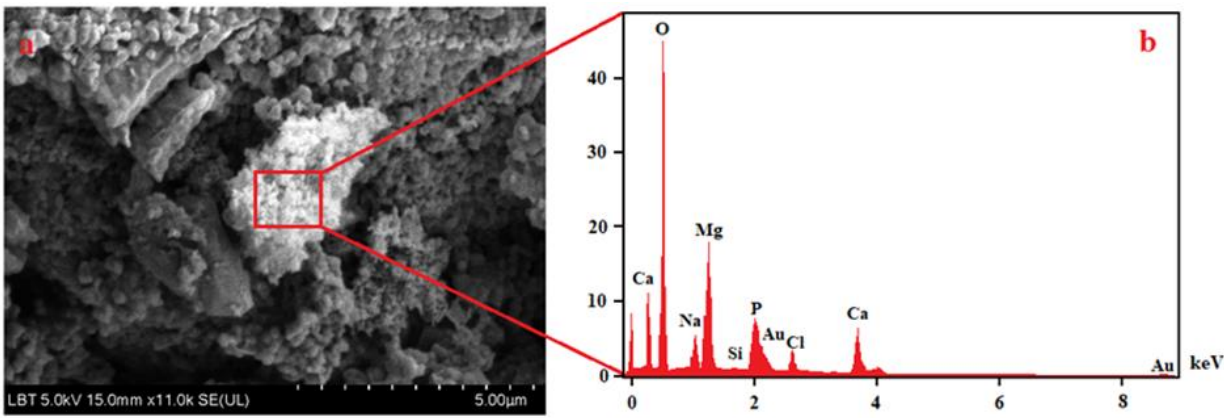

Fig. 6. SEM image (a) and EDS spectrum (b) for forsterite ceramic, FC-1400, fired at $1400{ }^{\circ} \mathrm{C}$, after 3 months of immersion in SBF

In both SEM images, Fig. 5 and Fig. 6, newly formed crystals of hydroxyapatite are highlighted on the surface of forsterite ceramics, FC-1200 and FC-1400, respectively. The EDS spectrum on the area containing hydroxyapatite crystals shows the presence of calcium and phosphorus along with silicon and magnesium, belonging to FCs. Thus, it is demonstrated that by maintaining FCs samples in SBF, hydroxyapatite crystals are initiated and grow on porous forsterite ceramics. It can be concluded that hydroxyapatite crystallites are formed and grow on the surface of forsterite ceramics.

\section{In vitro biocompatibility}

The FC-1200 scaffolds were investigated in human fibroblast from lung, HFL cells (ATCC number: CCL-153, normal lung fibroblasts) to test the scaffolds` biocompatibility. Thus, HFL culture was used to evaluate the biological activity and the performance of forsterite ceramic, FC-1200, scaffolds using MTT assay. For this purpose, the pellets of FC-1200 were immersed into the fibroblasts culture. The HFL cells were cultured in Dulbecco's Modified Eagle's Medium/nutrient mixture F-12 HAM medium with $10 \%$ fetal calf serum.

The MTT assay measures cell viability in terms of enzymatic conversion of the MTT tetrazolium compound to water insoluble formazan crystals by the action of mitochondrial reductases present in viable cells [33-34]. The MTT, 3-(4,5-dimethylthiazol-2-yl) -2,5 diphenyl-2H-tetrazolium bromide, water soluble dye readily penetrates viable HFL cells. MTT assay was carried out after cells culturing for 3, 7 and 14 days to investigate cell proliferation on FC-1200 scaffolds. Results are given as mean values in OD units taking into account the standard deviations, indicated as errors bars in Figure 7.

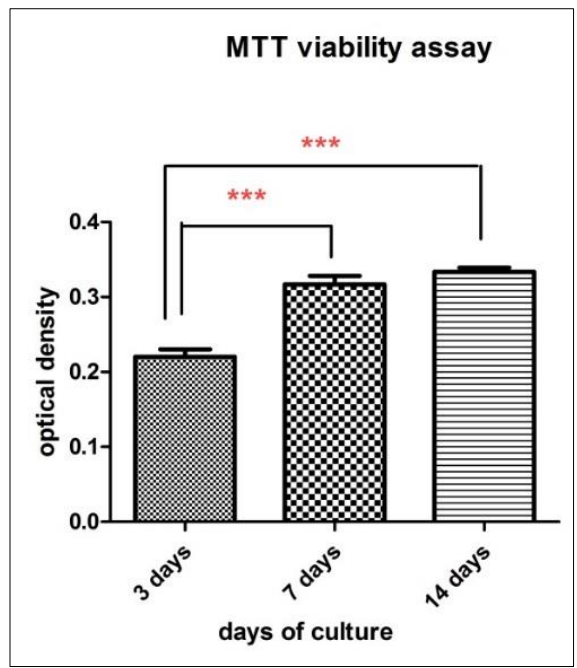

Fig. 7. Cell viability and proliferation rate, given as optical density (OD) units, of HFL cells cultivated on FC-1200 scaffolds for 3,7 and 14 days by using MTT test. Error bars stand for standard deviation (SD). Statistical analysis of OD (average values) indicates significant differences for $\mathrm{p}<0.001$ and are $(* * *)$ marked 
Figure 7 shows the results of the MTT assay for forsterite ceramic, fired at $1200{ }^{\circ} \mathrm{C}$, FC-1200, scaffolds for different time intervals in the HFL culture. Cell viability was evaluated with MTT test and revealed a gradual increase in cell proliferation on FC-1200 scaffolds, with statistically significant differences between the $3 \mathrm{~d}$ versus $7 \mathrm{~d}$ and between $3 \mathrm{~d}$ versus $14 \mathrm{~d}$, in fibroblasts culture $(\mathrm{p}<0.001)$, but without statistically significant difference between the $7 \mathrm{~d}$ and $14 \mathrm{~d}$, in cells culture, $\mathrm{p}>0.001$.

Therefore, cell density on the FC-1200 scaffolds increased with incubation time up to $7 \mathrm{~d}$ without significant increase between $7 \mathrm{~d}$ and $14 \mathrm{~d}$ post-seeding. The results indicate that the FC-1200 scaffolds can promote cell adhesion, proliferation and growth and in consequence have excellent biocompatibility.

Remarkably, these results are in substantial agreement with published data [5] using approximately the same discshape and size of similar forsterite biomaterial, especially at 7 days, when apparently the cell viability and proliferation expressed as OD units are almost at the same high level, although the cell culture used is completely different. Additionally, we tested this remark at 14 days in culture, and the cell proliferation is only slightly increased compared to the level reached at 7 days, and without statistical significance. Therefore, the highest level for cell viability and proliferation was reached at 7d on FC-1200 scaffolds in HFL culture, when the surface of scaffolds was completely covered with adhered cells.

Also, it is important to note that the used medium for cell culture in this investigation is rather comparable with that used previously [5], evidencing that the culture media is probably one of the most important factor in cell culture technology. However, the OD mean value at 3 days is significantly higher in the present investigation that the value reported previously, showing that in the early phase the importance of biomaterial scaffold can be crucial, particularly when used in vivo.

The superior performance of FC-1200 scaffolds at $3 \mathrm{~d}$ in HFL culture as illustrated by cell viability and proliferation can be also related to the surface roughness and irregular surface topography [40-43]. of these scaffolds. In this study, we noticed the surface roughness of FC-1200 scaffolds of $490 \pm 60 \mathrm{~nm}$ measured by AFM on scanned area of $10 \mu \mathrm{m} \times 10 \mu \mathrm{m}$ (unpublished results). Definitely, a rough surface can induce a better cell attachment than those presenting smooth surfaces, such as almost smooth glass surface. Therefore, the surface topography and roughness of forsterite ceramic, FC-1200, scaffolds might be an important factor to promote and support fibroblasts adhesion, proliferation and growth.

Based on these results, the FC-1200 scaffolds have a superior in vitro biocompatibility and might be considered as potential biomaterials for medical applications as bone substitutes.

\section{Conclusions}

Four novel porous forsterite ceramics were synthesized from nanostructured forsterite powders prepared by an original sol - gel method, by using the sintering process at $1200,1300,1400$ and $1450{ }^{\circ} \mathrm{C}$. Hence, four forsterite ceramics, FC-1200, FC-1300, FC-1400 and FC-1450 were sintered and characterized. The relative density, total porosity and linear shrinkage were determined to describe the porous characteristic of these forsterite ceramics. Relative density and linear shrinkage increased progressively with the increase in sintering temperature, while total porosity decreased gradually. Further, the bioactivity of these forsterite ceramics was evaluated in SBF at various time periods, 1, 2 and 3 months, by using XRD, FTIR and SEM-EDS, and the hydroxyapatite formation was determined on the surface of FC scaffolds immersed in SBF. The biocompatibility of forsterite ceramics as scaffolds in HFL culture was also studied by MTT assay. The novel FC-1200 provided a rather optimized porous scaffold in cell culture and revealed a superior performance in HFL culture, promoting attachment and proliferation of cells on forsterite ceramic surface.

These findings recommend the new porous forsterite ceramics, sintered between $1200{ }^{\circ} \mathrm{C}$ and $1450{ }^{\circ} \mathrm{C}$, as a good choice for bone implants owning a high ability to enhance cell adhesion and proliferation having also the chance to diminish the time for implant osseointegration and to accelerate tissue repair. Certainly, this quality will be deeply examined both in vitro and in vivo study, in the future for bone fracture healing and consolidation.

Acknowledgments: One of authors, Alexandra Avram would like to thank the Executive Agency for Higher Education, Research, Development and Innovation Funding (UEFISCDI) for financial support through the grant no. 83.

\section{References}

1.CHOUDHARY, R., CHATTERJEE, A., VENKATRAMAN, S. K., KOPPALA, S., ABRAHAM, J., SWAMIAPPAN, S., Bioact. Mater., 3, nr.

3,2018 , p. 218.

2. NURBAITI, U., DARMINTO, TRIWIKANTORO, ZAINURI, M., PRATAPA, S., Ceram. Int., 44, nr. 5, 2018 , p. 5543.

3. TAVANGARIAN, F., EMADI, R., Mater. Lett., 65, nr. 4, 2011, p. 740.

4. OH, S., OH, N., APPLEFORD, M., ONG, J. L., Am. J. Biochem. Biotechnol., 2, nr. 2, 2006, p. 49.

5. NI, S., CHOU, L., CHANG, J., Ceram. Int., 33, nr. 1, 2007, p. 83.

6. SANOSH, K. P., BALAKRISHNAN, A., FRANCIS, L., KIM, T. N., J. Alloys Compd., 495, 2010, p. 113.

7. TAVANGARIAN, F., EMADI, R., SHAFYEI, A., Powder Technol., 198, 2010, p. 412.

8. FATHI, M. H., KHARAZIHA, M., Mater. Lett., 63, nr. 17, 2009, p. 1455. 
9. KHARAZIHA, M., FATHI, M. H., J. Mech. Behav. Biomed. Mater., 3, nr. 7, 2010, p. 530.

10. TAVANGARIAN, F., FAHAMI, A., LI, G., KAZEMI, M., FORGHANI, A., J. Mater. Sci. Technol., 34, nr. 12, 2018 , p. 2263.

11. WANG, W. B., SHI, Z. M., WANG, X. G., WANG, Z. X., CAO, Z., FAN, W., J. Ceram. Soc. Jpn., 125, nr. 3, 2017 , p. 88.

12. SANO, S., SAITO, N., MATSUDA, S., OHASHI, N., HANEDA, H., ARITA, Y., TAKEMOTO, M., J. Am. Ceram. Soc., 89, nr. 2, 2006, p. 568.

13. CHOUDHARY, R., MANOHAR, P., VECSTAUDZA, J., YÁÑEZ-GASCÓN, M. J., PÉREZ SÁNCHEZ, H., NACHIMUTHU, R., LOCS, J., SWAMIAPPAN, S., Mater. Sci. Eng. C, 77, 2017, p. 811.

14. NAGHIU, M. A., GOREA, M., MUTCH, E., KRISTALY, F., TOMOAIA-COTISEL, M., J. Mater. Res. Technol., 29, nr. 7, 2013 , p. 628.

15. GOREA, M., NAGHIU, M. A., TOMOAIA-COTISEL, M., BORODI, G., 2013. Ceram.-Silikaty, 57, nr. 2, 2013 , p. 87.

16. NAGHIU, M. A., GOREA, M., KRISTALY, F., TOMOAIA-COTISEL, M., Ceram.-Silikaty, 58, nr. 4, 2014, p. 303.

17. FURTOS, G., NAGHIU, M. A., DEClERCQ, H., GOREA, M., PREJMEREAN, C., PANA, O., TOMOAIA-COTISEL, M., J. Biomed. Mater. Res. B, 104B, nr. 7, 2016, p. 1290.

18. RAMESH, S., YAGHOUBI, A., LEE, K. Y. S., CHIN, K. M. C., PURBOLAKSONO, J., HAMDI, M., HASSAN, M. A., J. Mech. Behav, Biomed. Mater., 25, 2013, p. 63.

19. MIRHADI, S. M., FORGHANI, A., TAVANGARIAN, F., Ceram. Int., 42, nr. 7, 2016, p. 7974.

20. GHOMI, H., JABERZADEH, M., FATHI, M. H., J. Alloy. Compd., 509, nr. 5, 2011, p. L63.

21. CHEN, S., ZHOU, X., SONG, W., SUN, J., ZHANG, H., JIANG, J., DENG, L., DONG, S., CAO, X., J. Eur. Ceram. Soc., 39, nr. 7, 2019 , p. 2397.

22. XIE, Y., ZHAI, W., CHEN, L., CHANG, J., ZHENG, X., DING, C., Acta Biomater., 5, nr. 6, 2009, p. 2331.

23. RIOS-PIMENTEL, F. F., CHANG, R., WEBSTER, T. J., MENDEZ-GONZALEZ, M. M., GARCÍA-ROCHA, M., Int. J. Nanomed., 14, 2019 , p. 3265.

24. SAQAEI, M., FATHI, M., EDRIS, H., MORTAZAVI, V., Mater. Sci. Eng. C, 56, 2015, p. 409.

25. SAQAEI, M., FATHI, M., EDRIS, H., MORTAZAVI, V., HOSSEINI N., Adv. Powder Technol., 27, nr. 5, 2016 , p. 1922.

26. KOKUBO, T., TAKADAMA. H., Biomaterials, 27, nr. 15, 2006, p. 2907.

27. GAO, C., PENG, S., FENG, P., SHUAI, C., Bone Res., 5, article nr.17059, 2017, p. 1.

28. FENG, P., WU, P., GAO, C., YANG, Y., GUO, W., YANG, W., SHUAI, C., Adv. Sci., 5, article nr. 1700817, 2018 , p. 1.

29. LEE, K. Y. S., CHIN, K. M. C., RAMESH, S., PURBOLAKSONO, J., HASSAN, M. A., HAMDI, M., TENG., W. D., J. Ceram. Process. Res., 14, nr. 1, 2013, p.131.

30. LIN, K., ZHAI, W., NI, S., CHANG, J., ZENG, Y., QIAN, W., Ceram. Int., 31, nr. 2, 2005, p. 323.

31. ZABIHI, M., AYATOLLAHI, M. R., REZAIE, H. R., Theor. Appl. Fract. Mech., 94, 2018, p. 173.

32. MA, L., WEN, D., DING, D., Mater. Res. Express, 6, nr. 7, article nr. 075062, 2019, p. 1.

33. IZQUIERDO-BARBA, I., SALINAS, A. J., VALLET-REGI, M., J. Biomed. Mater. Res., 51, nr. 2, 2000, p. 191.

34. RAPUNTEAN, S., FRANGOPOL, P. T., HODISAN, I., TOMOAIA, G., OLTEAN-DAN, D., MOCANU, A., PREJMEREAN, C., SORITAU, O., RACZ, L. Z., TOMOAIA-COTISEL, M., Rev. Chim., 69, no. 12, 2018, p. 3537.

35. VAN TONDER, A., JOUBERT, A. M., CROMARTY, A. D., BMC Res. Notes, 8, article nr. 47, 2015, p. 1.

36. TOMOAIA, G., SORITAU, O., TOMOAIA-COTISEL, M., POP, L. B., POP, A., MOCANU, A., HOROVITZ, O., BOBOS, L. D., Powder Technol., 238, 2013, p. 99.

37. TOMOAIA, G., MOCANU, A., VIDA-SIMITI, I., JUMATE, N., BOBOS, L. D., SORITAU, O., TOMOAIA-COTISEL, M., Mat. Sci. Eng. C, 37, 2014, p. 37.

38. DIBA, M., KHARAZIHA, M., FATHI, M. H., GHOLIPOURMALEKABADI, M., SAMADIKUCHAKSARAEI, A., Compos. Sci. Technol., 72, nr. 6, 2012, p. 716 .

39. DUFRANE, D., DELlOYE, C., MCKAY, I. J., DE AZA, P. N., DE AZA, S., SCHNEIDER, Y. J., ANSEAU, M., J. Mater. Sci.: Mater. Med, 14, nr. 1, 2003, p. 33.

40. FRANGOPOL, P. T., CADENHEAD, D. A., TOMOAIA, G., MOCANU, A., TOMOAIA-COTISEL, M., Rev. Roum. Chim., 60, nr. 2-3, 2015 , p. 265.

41. GARBO, C., SindilARU, M., CARLEA, A., TOMOAIA, G., ALMASAN, V., PETEAN, I., MOCANU, A., HOROVITZ, O., TOMOAIACOTISEL, M., Particul. Sci. Technol., 35, nr. 1, 2017, p. 29.

42. PALtineAN, G. A., PETEAN, I., ARGHIR, G., MUNTEAN, D. F., BOBOS, L. D, TOMOAIA-COTISEL, M., Particul. Sci. Technol., 34, nr. 5, 2016, p. 580.

43. ZDRENGHEA, U. V., TOMOAIA, G., POP-TOADER, D.-V., MOCANU, A., HOROVITZ, O., TOMOAIA-COTISEL, M., Comb. Chem. High Throughput Screen., 14, nr. 4, 2011, p. 237.

Manuscript received: 6.08 .2019 